\title{
FAKTOR-FAKTOR YANG BERHUBUNGAN DENGAN PEMANFAATAN BUKU KIA
}

\author{
Laila Rahmi ${ }^{1}$ \\ Stikes Syedza Saintika Padang \\ Email: laila_sitiazzahra@yahoo.co.id \\ Ika Yulia Darma \\ Stikes Syedza Saintika Padang \\ Email: \\ Silvi Zaimy ${ }^{3}$ \\ Stikes Syedza Saintika Padang \\ Email:
}

\begin{abstract}
ABSTRAK
Strategi utama Kementerian Kesehatan Republik Indonesia dalam menurunkan Angka Kematian Ibu (AKI), Angka Kematian Bayi (AKB), dan Angka Kematian Balita (AKABA) adalah menggerakkan dan memberdayakan masyarakat untuk hidup sehat. Kebijakan dan berbagai upaya pemerintah untuk menurunkan angka kematian ibu, bayi dan balita antara lain dengan kegiatan Gerakan Sayang Ibu (GSI), Strategi Making Pregnency Safer dan pengadaan buku Kesehatan Ibu dan Anak (KIA). Penerapan buku KIA dengan benar akan membawa dampak yang baik terhadap peningkatan pengetahuan ibu dan keluarga akan kesehatan ibu dan anak, memberdayakan masyarakat untuk hidup sehat, meningkatkan akses masyarakat terhadap pelayanan kesehatan yang berkualitas, serta meningkatkan surveillance, monitoring dan informasi kesehatan. Optimalisasi pemanfaatan buku KIA ditingkat keluarga hanya akan terjadi jika tenaga kesehatan dan kader dapat menjelaskan dan memastikan ibu dan keluarga paham dengan isi buku KIA (Kemenkes RI, 2015). Tujuan penelitian adalah untuk mengetahui faktor-faktor yang berhubungan dengan Pemanfaatan Buku KIA. Penelitian ini merupakan penelitian deskriptif, dengan rancangan cross sectional, yang dilakukan di Wilayah Kerja Puskesmas Lubuk Buaya Padang pada bulan Oktober tahun 2017 sampai dengan bulan Maret 2018. Populasi adalah semua ibu hamil yang berada di lokasi penelitian yang berjumlah 1097 orang, dengan sampel 43 orang yang diambil dengan teknik Cluster Random Sampling. Data dianalisis dengan analisis univariat dan bivariat. Hasil penelitian didapatkan bahwa tidak ada hubungan tingkat pengetahuan ibu hamil dengan pemanfaatan buku KIA, ada hubungan sikap ibu hamil dengan pemanfaatan buku KIA, dan ada hubungan persepsi ibu hamil terhadap peran kader dengan pemanfaatan buku KIA. Diharapkan kepada petugas kesehatan khususnya bidan lebih mengefisienkan kegiatan penyuluhan tentang pemanfaatan buku KIA pada ibu hamil dan lebih meningkatkan peran serta kader dalam upaya meningkatkan kesadaran ibu hamil dalam memanfaatkan buku KIA pada setiap kali melakukan kunjungan kehamilan.
\end{abstract}

Kata Kunci : Pemanfaatan Buku KIA, Tingkat Pengetahuan, Sikap, Persepsi terhadap Peran Kader

\begin{abstract}
The main strategy of Ministry of Health of the Republic of Indonesia in reducing Maternal Mortality Rate, Infant Mortality Rate), and Underfive Mortality Rate is to mobilize and empower people to live healthy. Policy and various government efforts to reduce maternal mortality, infants and toddlers, among others, with the activities of Mother Love Movement, Making Pregnancy Safer Strategy and Maternal Child Health (MCH) book procurement. Proper application of MCH book will have a good impact on improving mother and family knowledge on maternal and child health, empowering people to live healthy, increasing people's access to quality health services, and improving surveillance, monitoring and health information. The optimization of the use of MCH book at family level will only occur if health workers and cadres can explain and make sure the mother and family are familiar with the contents of MCH book (Kemenkes RI, 2015). The purpose of this research is to know the factors related to the utilization of MSH Book. This research is a descriptive research, with cross sectional design, conducted in the Work Area of Lubuk Buaya Padang Public Health Center from October 2017 until March 2018. The population is all pregnant women in the study area of 1097 people, with a sample of 43 people taken with Cluster Random Sampling technique. Data were analyzed by univariate and bivariate analysis. The result of the research shows that there is no correlation between knowledge level of pregnant mother with the utilization of MCH book, there is correlation between attitude of pregnant mother with utilization of $\mathrm{MCH}$ book, and there is relation of perception of pregnant mother to cadre role with utilization of $\mathrm{MCH}$ book. It is hoped that health officers, especially midwives, are more efficient in extension activities about the utilization of MCH book in pregnant mothers and more to increase cadre's role in improving awareness of pregnant women in utilizing MCH book during every pregnancy visit.
\end{abstract}

Keywords: Utilization of MCH Book, Level of Knowledge, Attitude, Perception on Role of Cadre

\section{PENDAHULUAN}

Program pembangunan kesehatan di Indonesia dewasa ini masih diprioritaskan pada upaya peningkatan derajat kesehatan Ibu dan anak, terutama pada kelompok yang paling rentan kesehatan yaitu ibu hamil, bersalin dan bayi pada masa perinatal. Hal ini ditandai dengan tingginya Angka Kematian
Ibu (AKI) dan Angka Kematian Bayi (AKB). AKI pada tahun 2013 sebesar 359 per 100.000 kelahiran hidup, diharapkan pada akhir tahun 2015 menjadi 102 per 100.000 kelahiran hidup. Sedangkan Angka Kematian Bayi (AKB) 32 per 1000 kelahiran hidup, diharapkan menjadi 23 per 1000 kelahiran hidup (Kemenkes RI, 2013). 
Strategi utama Kementerian Kesehatan Republik Indonesia dalam menurunkan AKI, AKB dan Angka Kematian Balita (AKABA) adalah menggerakkan dan memberdayakan masyarakat untuk hidup sehat. Kebijakan dan berbagai upaya pemerintah untuk menurunkan angka kematian ibu, bayi dan balita antara lain dengan kegiatan Gerakan Sayang Ibu (GSI), Strategi Making Pregnency Safer dan pengadaan buku KIA. Sejak tahun 1993-1994 untuk meningkatkan mutu pelayanan kesehatan khususnya pelayanan antenatal, pemerintah melalui kerjasama dengan Japan International Coorpertion Agency (JICA) guna mengembangkan buku Kesehatan Ibu dan Anak yang mulai di luncurkan pada tahun 2003 dan diuji coba di salah satu kota di Jawa Tengah. Perkembangan sangat baik yakni melampauicakupan propinsi yang telah direncanakan, sehingga Depkes merasa perlu untuk menyusun buku KIA versi Nasional (Kemenkes RI, 2010).

Buku KIA merupakan buku catatan yang dimiliki oleh orang tua dan penyedia layanan kesehatan yang digunakan untuk melakukan pemantauan kesehatan ibu selama kehamilan, menilai pertumbuhan dan perkembangan anak. Buku KIA juga merupakan alat yang dapat memberikan informasi pendidikan kesehatan kepada orang tua secara perorangan, yang dapat digunakan dengan biaya yang relatif lebih murah. Informasi yang terdapat pada buku KIA ini memungkinkan untuk dapat digunakan sebagai sistem pelayanan kesehatan yang lebih baik lagi bagi ibu dan anak di masa datang (Takheuci, Sukagami, and Perez, 2016).

Buku KIA adalah buku pegangan yang komprehensif yang digunakan untuk mengintegrasikan pendokumentasian ke dalam satu buku. Buku KIA umumnya mencakup tentang asuhan antenatal care (asuhan selama kehamilan), persalinan, nifas, perawatan bayi baru lahir dan anak, imunisasi, serta keluarga berencana. Buku ini juga berisikan infomasi mengenai cara merawat bayi dan anak dengan benar yang sangat bermanfaat bagi ibu lengkap dengan gambarnya sehingga dapat dengan mudah dipahami walaupun ibunya buta huruf (Yanagisawa, S, Soyano, A, Igarahi, H, et al, 2015).

Hampir semua Propinsi di Indonesia mengunakan buku KIA untuk pelayanan antenatal. Pada tahun 2013, pengadaan buku KIA telah mencapai $65 \%$ dari perkiraan jumlah ibu hamil atau 5,5 juta ibu hamil. Menteri Kesehatan (Menkes) telah mensahkan buku KIA sebagai salah satu program prioritas di Indonesia, yang diharapkan buku KIA nantinya bisa menjadi instrumen pencatatan kesehatan ibu dan anak di tingkat keluarga, selain itu juga mampu meningkatkan komunikasi antara ibu dan petugas dalam rangka mendidik $\mathrm{ibu/} \mathrm{keluarga}$ tentang perawatan dan pemeliharaan KIA dan gizi di rumah (Kemenkes RI, 2014).

Buku KIA mulai diterapkan di Indonesia sejak tahun 1994 dan di Propinsi Sumatera Barat tahun 1997, sedangkan untuk Kota Padang pada tahun 2000. Tingkat kepatuhan ibu menggunakan Buku KIA (Bringing Rate) di Propinsi Sumatera Barat tahun 2013 dengan target $95 \%$, baru tercapai 80,6\%. Di Kota Padang Bringing Rate buku KIA tercapai 72,2\% (Dinas Kesehatan Kota Padang, 2013).

Pemanfaatan buku KIA diharapkan dapat meningkatkan kualitas pelayanan Kesehatan Ibu dan Anak serta gizi sehingga salah satu tujuan pembangunan kesehatan nasional yaitu penurunan AKI dan AKB dapat tercapai. Penyebarluasan pemanfaatan Buku KIA dilakukan melalui
Puskesmas, Rumah Sakit, kegiatan Posyandu dan lain-lain dengan tujuan agar terjadi peningkatan kualitas pelayanan. Selain itu buku KIA dapat pula dipakai sebagai alat pemantau kesehatan ibu dan anak, serta pendidikan dan penyuluhan kesehatan bagi masyarakat (Kemenkes RI, 2011).

Penerapan buku KIA dengan benar akan membawa dampak yang baik terhadap peningkatan pengetahuan ibu dan keluarga akan kesehatan ibu dan anak, memberdayakan masyarakat untuk hidup sehat, meningkatkan akses masyarakat terhadap pelayanan kesehatan yang berkualitas, serta meningkatkan surveillance, monitoring dan informasi kesehatan (Kemenkes RI, 2015).

Optimalisasi pemanfaatan buku KIA di tingkat keluarga hanya akan terjadi jika tenaga kesehatan dan kader dapat menjelaskan dan memastikan ibu dan keluarga paham dengan isi buku KIA. Peningkatan pemanfaatan buku KIA ini dapat dilakukan dengan berbagai cara, diantaranya adalah dengan meningkatkan peran serta kader, karena kader dapat menjadi fasilitator terhadap ibu dan keluarga dalam memanfaatkan buku KIA serta merupakan penghubung antara masyarakat dengan tenaga kesehatan sehingga semua program yang akan dilaksanakan oleh tenaga kesehatan dapat dengan mudah untuk bisa sampai kepada masyarakat tersebut (Kemenkes RI, 2015). Berdasarkan latar belakang masalah di atas, penelitian ini bertujuan untuk mengetahui faktor-faktor yang berhubungan dengan pemanfaatan buku KIA.

\section{METODE PENELITIAN}

Jenis penelitian ini adalah deskriptif, dengan rancangan cross sectional yaitu dengan melakukan identifikasi variabel independen dan dependen pada waktu yang bersamaan. Penelitian dilakukan pada bulan Oktober 2017 sampai dengan bulan Maret tahun 2018. Pengumpulan data primer dilakukan pada bulan Januari tahun 2018 di Kelurahan Lubuk Buaya Wilayah Kerja Puskesmas Lubuk Buaya Padang. Populasi pada penelitian ini adalah seluruh ibu hamil yang ada di Wilayah Kerja Puskesmas Lubuk Buaya Padang yang berjumlah 1097 orang. Besaran sampel yang digunakan sesuai dengan rumus besar sampel (n) (Arikunto, 2006), sehingga jumlah sampel pada penelitian ini berjumlah 43 orang. Pengambilan sampel dilakukan dengan teknik Cluster Random Sampling. Data yang digunakan pada penelitian ini adalah data primer, yaitu data yang diperoleh dari responden penelitian, dan data sekunder, yaitu data yang diperoleh dari Pembina wilayah di lokasi penelitian dan Puskesmas Lubuk Buaya Padang. Analisis data yang digunakan pada penelitian ini adalah analisis univariat untuk melihat variasi dari variabel yang diteliti, dan analisis bivariat untuk melihat hubungan antara variabel dependen dan independen.

\section{HASIL PENELITIAN}

1. Karakteristik Responden a. Pendidikan

Tabel 4.1

Distribusi Frekuensi Pendidikan Ibu Hamil di Kelurahan Lubuk Buaya Wilayah Kerja Puskesmas Lubuk Buaya Padang Tahun 2018

\begin{tabular}{cccc}
\hline No. & Pendidikan & f & \% \\
\hline 1 & SMA/SLTA & 9 & 20,9 \\
\hline 2 & D3 & 7 & 16,3 \\
\hline 3 & S1 & 24 & 55,8 \\
\hline 4 & S2 & 3 & 7 \\
\hline
\end{tabular}




Jumlah $43 \quad 100$

Pada tabel 4.1 dapat dilihat bahwa dari 43 responden, terdapat 24 responden $(55,8 \%)$ yang memiliki pendidikan Sarjana.

\section{b. Pekerjaan}

Tabel 4.2

Distribusi Frekuensi Pekerjaan Ibu Hamil di Kelurahan Lubuk Buaya Wilayah Kerja Puskesmas Lubuk Buaya Padang Tahun 2018

\begin{tabular}{cccc}
\hline No. & Pekerjaan & f & \% \\
\hline 1 & IRT & 8 & 18,6 \\
\hline 2 & Swasta & 16 & 37,2 \\
\hline 3 & Guru & 5 & 11,6 \\
\hline 4 & PNS & 14 & 32,6 \\
\hline & Jumlah & $\mathbf{4 3}$ & $\mathbf{1 0 0}$ \\
\hline
\end{tabular}

Pada tabel 4.2 dapat dilihat bahwa dari 43 responden, terdapat 16 responden $(37,2 \%)$ yang memiliki pekerjaan swasta.

2. Analisa Univariat

a. Pemanfaatan Buku KIA

Tabel 4.3

Distribusi Frekuensi Pemanfaatan Buku KIA oleh Ibu

Hamil di Kelurahan Lubuk Buaya Wilayah Kerja

Puskesmas Lubuk Buaya Padang Tahun 2018

\begin{tabular}{cccc}
\hline No. & Pemanfaatan Buku KIA & f & \% \\
\hline 1 & Tidak Memanfaatkan dengan Baik & 23 & 53,5 \\
\hline 2 & Memanfaatkan dengan Baik & 20 & 46,5 \\
\hline & Jumlah & $\mathbf{4 3}$ & $\mathbf{1 0 0}$ \\
\hline
\end{tabular}

Pada tabel 4.3 dapat diketahui bahwa dari 43 responden, terdapat 23 responden $(53,5 \%)$ yang tidak memanfaatkan buku KIA dengan baik.

b. Tingkat Pengetahuan Ibu Hamil

Tabel 4.4

Distribusi Frekuensi Tingkat Pengetahuan Ibu Hamil tentang Buku KIA di Kelurahan Lubuk Buaya Wilayah Kerja Puskesmas Lubuk Buaya Padang Tahun 2018

\begin{tabular}{cccc}
\hline No. & $\begin{array}{c}\text { Tingkat Pengetahuan } \\
\text { Ibu Hamil }\end{array}$ & $\mathbf{f}$ & $\boldsymbol{\%}$ \\
\hline 1 & Rendah & 21 & 48,8 \\
\hline 2 & Tinggi & 22 & 51,2 \\
\hline & Jumlah & $\mathbf{4 3}$ & $\mathbf{1 0 0}$ \\
\hline
\end{tabular}

Pada tabel 4.4 dapat diketahui bahwa dari 43 responden, terdapat 21 responden $(48,8 \%)$ yang memiliki tidak pengetahuan rendah tentang buku KIA.

c. Sikap Ibu Hamil

Tabel 4.5

Distribusi Frekuensi Sikap Ibu Hamil terhadap Pemanfaatan Buku KIA di Kelurahan Lubuk Buaya Wilayah Kerja Puskesmas Lubuk Buaya Padang Tahun 2018

No. Sikap Ibu Hamil f $\%$

\begin{tabular}{cccc}
\hline 1 & Negatif & 21 & 48,8 \\
\hline 2 & Positif & 22 & 51,2 \\
\hline & Jumlah & $\mathbf{4 3}$ & $\mathbf{1 0 0}$ \\
\hline
\end{tabular}

Pada tabel 4.5 dapat diketahui bahwa dari 43 responden, terdapat 21 responden $(48,8 \%)$ yang memiliki sikap negatif terhadap buku KIA.

\section{d. Persepsi Ibu Hamil terhadap Peran Kader}

Tabel 4.6

Distribusi Frekuensi Persepsi Ibu Hamil terhadap Peran Kader dalam Pemanfaatan Buku KIA di Kelurahan Lubuk Buaya Wilayah Kerja Puskesmas Lubuk Buaya Padang Tahun 2018

\begin{tabular}{cccc}
\hline No. & $\begin{array}{c}\text { Persepsi Ibu Hamil } \\
\text { terhadap Peran Kader }\end{array}$ & f & \% \\
\hline 1 & Negatif & 16 & 37,2 \\
\hline 2 & Positif & 27 & 62,8 \\
\hline & Jumlah & $\mathbf{4 3}$ & $\mathbf{1 0 0}$ \\
\hline
\end{tabular}

Pada tabel 4.6 dapat diketahui bahwa dari 43 responden, terdapat 16 responden $(37,2 \%)$ yang memiliki persepsi negatif terhadap peran kader dalam pemanfaatan buku KIA.

3. Analisa Bivariat

a. Hubungan Tingkat Pengetahuan dengan Pemanfaatan Buku KIA

Tabel 4.7

Hubungan Tingkat Pengetahuan Ibu Hamil dengan Pemanfaatan Buku KIA di Kelurahan Lubuk Buaya Wilayah Kerja Puskesmas Lubuk Buaya Padang Tahun 2018

\begin{tabular}{|c|c|c|c|c|c|c|c|c|}
\hline \multirow{3}{*}{ No. } & \multirow{3}{*}{$\begin{array}{c}\text { Tingkat } \\
\text { Pengetahuan } \\
\text { Ibu Hamil }\end{array}$} & \multicolumn{4}{|c|}{ Pemanfaatan Buku KIA } & \multirow{2}{*}{\multicolumn{2}{|c|}{ Total }} & \multirow[b]{2}{*}{$\underset{\text { value }}{\rho}$} \\
\hline & & \multicolumn{2}{|c|}{$\begin{array}{c}\text { Tidak } \\
\text { Memanfaatkan } \\
\text { dengan Baik }\end{array}$} & \multicolumn{2}{|c|}{$\begin{array}{c}\text { Memanfaatkan } \\
\text { dengan Baik }\end{array}$} & & & \\
\hline & & f & $\%$ & f & $\%$ & f & $\%$ & \multirow{4}{*}{1,000} \\
\hline 1 & Rendah & 11 & 52,4 & 10 & 47,6 & 21 & 100 & \\
\hline 2 & Tinggi & 12 & 54,5 & 10 & 45,5 & 22 & 100 & \\
\hline & Total & 23 & 53,5 & 20 & 46,5 & 43 & 100 & \\
\hline
\end{tabular}

Pada tabel 4.7 dapat dilihat bahwa, dari 21 responden dengan tingkat pengetahuan rendah, terdapat 11 responden $(52,4 \%)$ yang tidak memanfaatkan buku KIA dengan Baik. Setelah dilakukan uji statistik Chi-Square didapatkan $p$ value $=1,000$ ( $\mathrm{p}>0.05)$, berarti Ha ditolak dan Ho diterima, sehingga disimpulkan bahwa tidak ada hubungan antara tingkat pengetahuan ibu hamil tentang buku KIA dengan pemanfaatan buku KIA.

b. Hubungan Sikap Ibu Hamil dengan Pemanfaatan Buku KIA

Tabel 4.8

Hubungan Sikap Ibu Hamil dengan Pemanfaatan Buku KIA di Kelurahan Lubuk Buaya Wilayah Kerja Puskesmas Lubuk Buaya Padang Tahun 2018

\begin{tabular}{|c|c|c|c|c|c|c|c|c|}
\hline \multirow{3}{*}{ No. } & \multirow{3}{*}{$\begin{array}{l}\text { Sikap } \\
\text { Ibu } \\
\text { Hamil }\end{array}$} & \multicolumn{4}{|c|}{ Pemanfaatan Buku KIA } & \multirow{2}{*}{\multicolumn{2}{|c|}{ Total }} & \multirow[b]{2}{*}{ pvalue } \\
\hline & & \multicolumn{2}{|c|}{$\begin{array}{c}\text { Tidak } \\
\text { Memanfaatkan } \\
\text { dengan Baik }\end{array}$} & \multicolumn{2}{|c|}{$\begin{array}{c}\text { Memanfaatkan } \\
\text { dengan Baik }\end{array}$} & & & \\
\hline & & $\mathbf{f}$ & $\%$ & f & $\%$ & f & $\%$ & \multirow{4}{*}{0,046} \\
\hline 1 & Negatif & 15 & 71,4 & 6 & 28,6 & 21 & 100 & \\
\hline 2 & Positif & 8 & 36,4 & 14 & 63,6 & 22 & 100 & \\
\hline & Total & 23 & 53,5 & 20 & 46,5 & 43 & 100 & \\
\hline
\end{tabular}


Pada tabel 4.8 dapat dilihat bahwa, dari 21 responden dengan sikap negatif, terdapat 15 responden $(71,4 \%)$ yang tidak memanfaatkan buku KIA dengan baik.

Setelah dilakukan uji statistik Chi-Square didapatkan $p$ value $=0,046(\mathrm{p}<0.05)$, berarti Ha diterima dan Ho ditolak, sehingga disimpulkan bahwa ada hubungan antara sikap ibu hamil tentang buku KIA dengan pemanfaatan buku KIA.

c. Hubungan Persepsi Ibu Hamil terhadap Peran Kader dengan Pemanfaatan Buku KIA

Tabel 4.9

Hubungan Persepsi Ibu Hamil terhadap Peran Kader dengan Pemanfaatan Buku KIA di Kelurahan Lubuk Buaya Wilayah Kerja Puskesmas Lubuk Buaya Padang Tahun 2018

\begin{tabular}{|c|c|c|c|c|c|c|c|c|}
\hline \multirow{3}{*}{ No. } & \multirow{3}{*}{$\begin{array}{c}\text { Persepsi } \\
\text { Ibu Hamil } \\
\text { terhadap } \\
\text { Peran Kader }\end{array}$} & \multicolumn{4}{|c|}{ Pemanfaatan Buku KIA } & \multirow{2}{*}{\multicolumn{2}{|c|}{ Total }} & \multirow[b]{2}{*}{$\underset{\text { value }}{\rho}$} \\
\hline & & \multicolumn{2}{|c|}{$\begin{array}{c}\text { Tidak } \\
\text { Memanfaatkan } \\
\text { dengan Baik }\end{array}$} & \multicolumn{2}{|c|}{$\begin{array}{c}\text { Memanfaatkan } \\
\text { dengan Baik }\end{array}$} & & & \\
\hline & & $\mathbf{f}$ & $\%$ & $\mathbf{f}$ & $\%$ & f & $\%$ & \multirow{4}{*}{0,000} \\
\hline 1 & Negatif & 15 & 93,8 & 1 & 6,2 & 16 & 100 & \\
\hline 2 & Positif & 8 & 29,6 & 19 & 70,4 & 27 & 100 & \\
\hline & Total & 23 & 53,5 & 20 & 46,5 & 43 & 100 & \\
\hline
\end{tabular}

Pada tabel 4.9 dapat dilihat bahwa, dari 16 responden dengan persepsi negatif terhadap peran kader, terdapat 15 responden $(71,4 \%)$ yang tidak memanfaatkan buku KIA dengan baik.

Setelah dilakukan uji statistik Chi-Square didapatkan $p$ value $=0,000(\mathrm{p}<0.05)$, berarti Ha diterima dan Ho ditolak, sehingga disimpulkan bahwa ada hubungan antara persepsi hamil terhadap peran kader tentang buku KIA dengan pemanfaatan buku KIA.

\section{PEMBAHASAN}

\section{Pemanfaatan Buku KIA}

Pada hasil penelitian didapatkan bahwa dari 43 responden, terdapat 23 responden $(53,5 \%)$ yang tidak memanfaatkan buku KIA dengan baik.

Hasil penelitian ini selaras dengan hasil penelitian yang telah dilakukan oleh Herlita (2010) tentang hubungan faktor predisposing, enabling, reinforcing dengan pemanfaatan buku KIA di Puskesmas Kota Alam Banda Aceh, yang menemukan bahwa lebih dari separoh (55\%) ibu hamil tidak memanfaatkan buku KIA dalam melakukan kunjungan kehamilan. Berbeda dengan hasil penelitian yang dilakukan oleh Sistiarani, Gamelia, Hariyadi (2014) tentang analisis kualitas penggunaan Buku KIA, didapatkan bahwa sebagian besar responden (52\%) memiliki kualitas yang baik dalam penggunaan buku KIA dan sebagian besar responden (78\%) membawa buku KIA ketika berkunjung ke puskesmas.

Buku KIA merupakan salah satu alat yang berisi catatan kesehatan ibu (hamil, bersalin dan nifas) dan anak (bayi baru lahir, bayi dan anak) serta berbagai informasi cara memelihara dan merawat kesehatan ibu dan anak (Kemenkes RI, 2015).

Menurut asumsi peneliti, masih adanya ibu hamil yang tidak memanfaatkan buku KIA disebabkan oleh masih kurangnya kesadaran dan kepekaan ibu hamil dalam memanfaatkan buku KIA pada setiap melakukan kunjungan kehamilan dengan tenaga kesehatan di fasilitas pelayanan kesehatan. Selain itu juga disebabkan oleh karena ibu merasa tidak membutuhkan buku KIA, karena tanpa buku KIA pemeriksaan tetap bisa dilakukan dan hasilnya bisa dicatat sendiri oleh ibu hamil walaupun pencatatannya tidak dilakukan di buku KIA. Buku KIA yang tidak dimanfaatkan dengan baik oleh ibu hamil pada penelitian ini juga dipengaruhi oleh faktor pekerjaan ibu yang sebagaian besar adalah bekerja $(81,4 \%)$, dengan alasan pekerjaan, ibu hamil mengatakan karena faktor kelelahan dan sering lupa menjadi alasan bagi ibu hamil tidak membawa KIA saat melakukan kunjungan kehamilan.

\section{Tingkat Pengetahuan Ibu Hamil}

Pada hasil penelitian didapatkan bahwa dari 43 responden, terdapat 21 responden $(48,8 \%)$ yang memiliki tidak pengetahuan rendah tentang buku KIA.

Hasil penelitian ini sama dengan hasil penelitian yang dilakukan oleh Dian Purnama (2009) tentang gambaran tingkat pengetahuan dan sikap ibu balita terhadap pemanfaatan buku KIA di Puskesmas Nanggalo Padang yang didapatkan hasil bahwa sebagian kecil $(37,1 \%)$ ibu balita berpengetahuan rendah tentang buku KIA. Selaras dengan penelitian yang dilakukan oleh Sistiarani, Gamelia, Hariyadi (2014) tentang analisis kualitas penggunaan Buku KIA, didapatkan bahwa sebagian besar responden (78\%) memiliki pengetahuan yang baik tentang buku KIA.

Pengetahuan merupakan hasil dari tahu dan ini terjadi setelah orang melakukan penginderaan terhadap suatu objek tertentu. Penginderaan terjadi melalui panca indera manusia, yakni indra penglihatan, pendengaran, penciuman, rasa dan raba. Sebagian besar pengetahuan manusia diperoleh melalui mata dan telinga (Notoatmodjo, 2012).

Menurut asumsi peneliti terhadap hasil jawaban pada butir pertanyaan yang terdapat pada kuesioner penelitian, terdapat 8 pertanyaan dari 20 pertanyaan yang diajukan kurang dari separoh ibu hamil tidak menjawab pertanyaan dengan benar, 2 pertanyaan dengan persentase jawaban benar terendah $(44,2 \%)$ adalah pertanyaan mengenai isi buku KIA dan perawatan ibu hamil yang terdapat pada buku KIA. Namun dilihat secara keseluruhan dapat diketahui bahwa sebagian besar $(51,2 \%)$ ibu hamil sudah memiliki tingkat pengetahuan yang tinggi terhadap buku KIA. Hal ini sehubungan dengan latar belakang pendidikan ibu hamil yang sudah tinggi ( $\geq$ SMA/ SLTA), bahkan 79,1\% diantaranya sudah merupakan tamatan perguruan tinggi.

\section{Sikap}

Pada hasil penelitian didapatkan bahwa dari 43 responden, terdapat 21 responden $(48,8 \%)$ yang memiliki sikap negatif terhadap buku KIA.

Hasil penelitian ini sama dengan hasil penelitian yang dilakukan oleh Widagdo dan Husodo (2009) tentang pemanfaatan buku KIA oleh kader posyandu di Wilayah Kerja Puskesmas Kedungadem Kabupaten Bojonegoro yang didapatkan hasil bahwa sebagian besar responden $(52,5 \%)$ memiliki sikap yang baik terhadap pemanfaatan buku KIA. Namun hasil penelitian ini berbeda dengan hasil penelitian Dian, P (2009) tentang gambaran tingkat pengetahuan dan sikap ibu balita terhadap pemanfaatan buku KIA di Puskesmas Nanggalo 
Padang yang didapatkan hasil sebagian besar (59\%) ibu balita bersikap negatif terhadap pemanfaatan buku KIA.

Sikap merupakan reaksi atau respons yang masih tertutup dari seseorang terhadap stimulus atau objek. Sedangkan menurut seorang ahli psikologi sosial Newcomb mengatakan bahwa sikap merupakan kesiapan atau kesediaan untuk bertindak, dan bukan merupakan pelaksanaan motif tertentu (Notoatmodjo, 2012).

Menurut asumsi peneliti, terhadap hasil jawaban pada butir pernyataan yang terdapat pada kuesioner penelitian, dimana terhadap 9 pernyataan negatif yang ada pada kuesioner secara keseluruhan ibu hamil memberikan respon yang juga negatif, 3 pernyataan diantaranya yang paling direspon negatif oleh ibu hamil adalah pada pernyataan "Buku KIA menambah beban saya dan keluarga dalam memahami informasi kesehatan", "Pencatatan yang ada di tempat pelayanan kesehatan lebih lengkap dan membantu dalam pencatatan kesehatan ibu dan anak dibandingkan dengan buku KIA", dan "Peranan buku KIA bagi saya dan anak, sama seperti buku bacaan dan majalah kesehatan lainnya". Sementara pada 11 pernyataan positif yang ada pada kuesioner secara keseluruhan ibu hamil memberikan respon yang juga positif, 3 pernyataan diantaranya yang kurang direspon positif oleh ibu hamil adalah pada pernyataan "Buku KIA harus disosialisasikan kepada seluruh masyarakat oleh petugas kesehatan", "Buku KIA merupakan sarana untuk mempersiapkan ibu hamil dan melahirkan dengan aman, bayi sehat dan ibu selamat", dan "buku KIA dapat meningkatkan pengetahuan dan pemahaman saya dan keluarga tentang pemeliharaan kesehatan ibu dan anak"

Namun dilihat secara keseluruhan dapat diketahui bahwa sebagian besar $(51,2 \%)$ ibu hamil sudah memberikan respon yang positif terhadap pemanfaatan buku KIA. Hal ini juga sehubungan dengan latar belakang pendidikan ibu hamil yang sudah tinggi ( $\geq$ SMA/ SLTA), bahkan $79,1 \%$ diantaranya sudah merupakan tamatan perguruan tinggi, sehingga segala sesuatu dapat direspon dengan baik.

\section{Persepsi Ibu Hamil terhadap Peran Kader}

Pada hasil penelitian didapatkan bahwa dari 43 responden, terdapat 16 responden $(37,2 \%)$ yang memiliki persepsi negatif terhadap peran kader dalam pemanfaatan buku KIA.

Hasil penelitian ini selaras dengan hasil penelitian yang dilakukan oleh Rahayu (2014) tentang hubungan dukungan keluarga dan peran kader terhadap pemanfaatan buku KIA di Wilayah Kerja Puskesmas Bungus Padang yang didapatkan hasil bahwa hanya sebagian kecil $(23,7 \%)$ kader yang tidak berperan dalam pemanfaatan buku KIA. Sama halnya dengan penelitian yang dilakukan oleh Widagdo dan Husodo (2009) tentang pemanfaatan buku KIA oleh kader posyandu yang didapatkna hasil bahwa sebagian besar (76,6\% dan $56,3 \%$ ) kader memiliki peran yang baik sebagai pelaksana dan pengelola buku KIA.

Optimalisasi pemanfaatan buku KIA di tingkat keluarga hanya akan terjadi jika tenaga kesehatan dan kader dapat menjelaskan dan memastikan ibu dan keluarga paham dengan isi buku KIA. Peningkatan pemanfaatan buku KIA ini dapat dilakukan dengan berbagai cara, diantaranya adalah dengan meningkatkan peran serta kader, karena kader dapat menjadi fasilitator terhadap ibu dan keluarga dalam memanfaatkan buku KIA serta merupakan penghubung antara masyarakat dengan tenaga kesehatan sehingga semua program yang akan dilaksanakan oleh tenaga kesehatan dapat dengan mudah untuk bisa sampai kepada masyarakat tersebut (Kemenkes RI, 2015).

Menurut asumsi peneliti, terhadap hasil jawaban yang diberikan pada butir pernyataan yang terdapat pada kuesioner penelitian, dimana terhadap 4 pernyataan negatif yang ada pada kuesioner secara keseluruhan ibu hamil memberikan respon yang juga negatif, pernyataan yang paling direspon negatif oleh ibu hamil adalah pada pernyataan "Kader sulit ditemui saat saya ingin menanyakan tentang buku KIA".

Namun dilihat secara keseluruhan dapat diketahui bahwa sebagian besar $(62,7 \%)$ ibu hamil memiliki persepsi yang positif terhadap peran kader terhadap pemanfaatan buku KIA. Berdasarkan informasi yang didapatkan oleh peneliti dari Petugas Kesehatan Pembina Wilayah di lokasi penelitian diperoleh informasi bahwa kader ibu hamil di wilayahnya sudah mendapatkan pembinaan dari pihak Puskesmas dan sudah sering diingatkan untuk lebih bisa berperan serta aktif di masyarakat dengan ikut serta meningkatkan cakupan pelayanan kesehatan yang ada di Puskesmas dan Posyandu sehingga secara bersama antara kader dan petugas puskemas dapat meningkatkan pemberdayaan masyarakat dengan baik.

\section{Hubungan Tingkat Pengetahuan Ibu Hamil dengan Pemanfaatan Buku KIA}

Pada hasil penelitian didapatkan bahwa dari 21 responden dengan tingkat pengetahuan rendah, terdapat 11 responden $(52,4 \%)$ yang tidak memanfaatkan buku KIA dengan baik. Setelah dilakukan uji statistik ChiSquare didapatkan $p$ value $=1,000(\mathrm{p}>0.05)$, berarti Ha ditolak dan Ho diterima, sehingga disimpulkan bahwa tidak ada hubungan antara tingkat pengetahuan ibu hamil tentang buku KIA dengan pemanfaatan buku KIA.

Hasil penelitian ini senada dengan hasil penelitian yang telah dilakukan oleh Herlita (2010) tentang hubungan faktor predisposing, enabling, reinforcing dengan pemanfaatan buku KIA di Puskesmas Kota Alam Banda Aceh, dimana ditemukan bahwa tidak adanya hubungan antara tingkat pengetahuan ibu dengan pemanfaatan buku KIA ( $>>0,05)$. Berbeda dengan penelitian yang dilakukan oleh Sistiarani, Gamelia, Hariyadi (2014) tentang analisis kualitas penggunaan Buku KIA, didapatkan bahwa ada hubungan antara pengetahuan tentang buku KIA dengan kualitas penggunaan buku KIA ( $\mathrm{p}<0,05)$

Pada ibu yang berpengetahuan rendah akan terlihat pada perilaku ibu dalam memanfaatkan buku KIA seperti ibu lupa membawa buku KIA ketika ketempat pelayanan kesehatan untuk periksa kehamilan, sehingga ibu lebih sulit dalam mengetahui tentang kehamilan dan kondisi janinnya. Dalam buku KIA berisi catatan mengenai perkembangan kehamilan pada ibu hamil (Herlita, 2010). 
Menurut asumsi peneliti, tidak adanya hubungan antara tingkat pengetahuan ibu hamil dengan pemanfaatan buku KIA pada penelitian ini terjadi karena tingkat pengetahuan ibu hamil yang tinggi terhadap buku KIA pada penelitian ini tidak memiliki pengaruh terhadap ibu dalam memanfaatkan buku KIAnya dengan baik. Tingkat pengetahuan ibu yang tinggi lebih disebabkan karena secara keseluruhan ibu hamil pada penelitian ini sudah memiliki tingkat pendidikan yang tinggi, bahkan $79,1 \%$ diantaranya sudah merupakan tamatan perguruan tinggi.

\section{Hubungan Sikap Ibu Hamil dengan Pemanfaatan Buku KIA}

Pada hasil penelitian didapatkan bahwa dari 21 responden dengan sikap negatif, terdapat 15 responden $(71,4 \%)$ yang tidak memanfaatkan buku KIA dengan baik. Setelah dilakukan uji statistik Chi-Square didapatkan $p$ value $=0,046(\mathrm{p}<0.05)$, berarti Ha diterima dan Ho ditolak, sehingga disimpulkan bahwa ada hubungan antara sikap ibu hamil tentang buku KIA dengan pemanfaatan buku KIA.

Hasil penelitian ini sama dengan hasil penelitian yang telah dilakukan oleh Herlita (2010) tentang hubungan faktor predisposing, enabling, reinforcing dengan pemanfaatan buku KIA di Puskesmas Kota Alam Banda Aceh, dimana pada hasil penelitian ditemukan bahwa adanya hubungan sikap ibu dengan pemanfaatan buku KIA.

Pada ibu hamil yang memiliki sikap negatif terhadap pemanfaatan buku KIA memberikan dampak kurangnya dukungan atau motivasi dari keluarga tentang pemanfaatan buku KIA yang mana ibu hamil akan susah untuk memperoleh informasi lengkap tentang KIA serta jenis pelayanan kesehatan yang dapat di tempat pelayanan kesehatan. Manifestasi sikap tidak dapat langsung dilihat, tetapi hanya dapat ditafsirkan terlebih dahulu, untuk mengambil suatu keputusan terhadap suatu perubahan atau stimulus. Sikap ibu terwujud dari tingkat pemahamannya tentang pentingnya manfaat buku KIA (Herlita, 2010).

Menurut asumsi peneliti, terdapatnya hubungan sikap ibu hamil dengan pemanfaatan buku KIA karena sikap positif merupakan dasar atau kesiapan ibu hamil untuk memanfaatkan buku KIA, dengan sikap yang positif ibu hamil cenderung untuk selalu membawa buku KIA pada setiap kali melakukan kunjungan kehamilan ke petugas kesehatan di fasilitas pelayanan kesehatan. Sebaliknya jika ibu hamil bersikap negatif terhadap buku KIA maka adanya kecenderungan ibu hamil untuk tidak membawa buku KIA pada setiap kali melakukan kunjungan kehamilan ke petugas kesehatan di fasilitas pelayanan kesehatan. Pada penelitian ini ditemukan bahwa ibu hamil yang bersikap negatif cenderung tidak memanfaatkan buku KIA dengan baik karena faktor pekerjaan ibu, dengan alasan pekerjaan, ibu hamil mengatakan karena kelelahan dan sering lupa, menjadi alasan bagi ibu hamil tidak membawa KIA saat melakukan kunjungan kehamilan. Selain daripada itu, adanya anggapan ibu hamil bahwa tanpa membawa buku KIA, pemeriksaan akan tetap dilakukan dan pencatatan yang dilakukan pada fasilitas pelayanan tempat ibu hamil melakukan pemeriksaan kehamilan sudah dirasakan lengkap oleh ibu menjadi juga menjadi alasan bagi ibu untuk tidak membawa buku KIA dalam melakukan pemeriksaan kehamilan.

\section{Hubungan Persepsi Ibu Hamil terhadap Peran Kader dengan Pemanfaatan Buku KIA}

Pada hasil penelitian didapatkan bahwa dari 16 responden dengan persepsi negatif terhadap peran kader, terdapat 15 responden $(71,4 \%)$ yang tidak memanfaatkan buku KIA dengan baik. Setelah dilakukan uji statistik Chi-Square didapatkan $p$ value $=0,000(\mathrm{p}<0.05)$, berarti Ha diterima dan Ho ditolak, sehingga disimpulkan bahwa ada hubungan antara persepsi hamil terhadap peran kader tentang buku KIA dengan pemanfaatan buku KIA.

Hasil penelitian ini selaras dengan hasil penelitian yang dilakukan oleh Rahayu (2014) tentang hubungan dukungan keluarga dan peran kader terhadap pemanfaatan buku KIA di Wilayah Kerja Puskesmas Bungus Padang yang didapatkan hasil bahwa ada hubungan antara peran kader dengan pemanfaatan buku KIA oleh ibu hamil. Selaras dengan penelitian yang dilakukan oleh Widagdo dan Husodo (2009) tentang pemanfaatan buku KIA oleh kader posyandu di Wilayah Kerja Puskesmas Kedungadem Kabupaten Bojonegoro yang didapatkan hasil bahwa peran kader sebagai pelaksana dan pengelola berpengaruh terhadap pemanfaatan buku KIA.

Peningkatan pemanfaatan buku KIA dapat dilakukan dengan berbagai cara, diantaranya adalah dengan meningkatkan peran serta kader, karena kader dapat menjadi fasilitator terhadap ibu dan keluarga dalam memanfaatkan buku KIA serta merupakan penghubung antara masyarakat dengan tenaga kesehatan sehingga semua program yang akan dilaksanakan oleh tenaga kesehatan dapat dengan mudah untuk bisa sampai kepada masyarakat tersebut (Kemenkes RI, 2015).

Menurut asumsi peneliti, terdapatnya hubungan antara persepsi ibu hamil terhadap peran kader dengan pemanfaatan buku KIA karena kader sebagai bagian dari masyarakat yang juga dikenal baik oleh ibu hamil merupakan perpanjangan tangan dari petugas kesehatan untuk lebih intensif melakukan pendekatan dan penyuluhan kepada masyarakat khusunya ibu hamil yang memiliki lokasi tempat tinggal di sekitar tempat tinggal ibu hamil, sehingga ibu hamil yang memiliki persepsi positif terhadap peran kader cenderung memanfaatkan buku KIA dengan baik dalam melakukan kunjungan kehamilan.

\section{KESIMPULAN}

Tidak ada hubungan tingkat pengetahuan ibu hamil dengan pemanfaatan buku KIA di Wilayah Kerja Puskesmas Lubuk Buaya Padang.

Ada hubungan sikap ibu hamil dengan pemanfaatan buku KIA di Wilayah Kerja Puskesmas Lubuk Buaya Padang.

Ada hubungan persepsi ibu hamil terhadap peran kader dengan pemanfaatan buku KIA di Wilayah Kerja Puskesmas Lubuk Buaya Padang. 


\section{DAFTAR PUSTAKA}

Arikunto, 2006. Prosedur Penelitian Suatu Pendekatan Praktik. Jakarta; Rineka Cipta.

Dian, P. 2009. Gambaran Tingkat Pengetahuan dan Sikap Ibu Balita Terhadap Pemanfaatan Buku KIA di Puskesmas Nanggalo Padang. Padang; Skripsi.

Dinas Kesehatan Kota Padang, 2013. Laporan Tahunan Tahun 2012. DKK. Padang.

Herlita, 2010. Hubungan Faktor Predisposisi, Enabling dan Reinforcing Terhadap Pemanfaatan Buku KIA di Puskesmas Koto Alam Banda Aceh. Medan: Tesis FKM-USU.

Kemenkes RI, 2010. Petunjuk Teknis Penggunaan Buku KIA. Jakarta: Direktorat Jenderal Bina Kesehatan Masyarakat.

Kemenkes RI, 2011. Profil Data Kesehatan Indonesia Tahun 2011. Jakarta: Kemenkes RI.

Kemenkes RI, 2013. AKI dan AKB di Indonesia Tahun 2013. Jakarta: Kemenkes RI.

Kemenkes RI, 2014. Profil Kesehatan Indonesia Tahun 2014. Jakarta: Kemenkes RI.

Kemenkes RI, 2015. Petunjuk Teknis Penggunaan Buku KIA. Jakarta: Direktorat Jenderal Bina Kesehatan Masyarakat.
Notoatmodjo S, 2012. Promosi Kesehatan dan Perilaku Kesehatan. Jakarta: Rineka Cipta.

Rahayu, 2014. Hubungan dukungan keluarga dan peran kader terhadap pemanfaatan buku KIA di Wilayah Kerja Puskesmas Bungus Padang. Padang: Skripsi.

Sistiarani, Gamelia, Hariyadi, 2014. Analisis kualitas penggunaan Buku KIA. Jurnal Kesehatan Masyarakat. Kemas 10 (1). 14-20.

Takheuci, Sukagami, and Perez, 2016. The Mother and Child Health Handbook in Japan as a Health Promotion Tool; An Overview of Its History, Contents, Use, Benefits, and Global Influence. Global Pedriatric Health Volume 3: 19.

Widagdo dan Husodo, 2009. Pemanfaatan Buku KIA oleh Kader Posyandu: Studi pada Kader Posyandu di Wilayah Kerja Puskesmas Kedungadem Kabupaten Bojonegoro. Makara, Kesehatan, Vol. 13, No.1, Juni 2009: 39-47.

Yanagisawa, S, Soyano, A, Igarahi, H, et al, 2015. Effect of a Maternal and Child Health Handbook on Maternal Knowledge and Behaviour: a community-based controlled trial in rural Cambodia. Health Policy and Planning. 30: 1184-1192. 